\title{
THE SIGNIFICANCE OF HEINZ BODIES IN THE ERYTHROCYTE
}

\author{
BY \\ MONAMY BUCKELL and J. DEREK RICHARDSON \\ From the Department for Research in Industrial Medicine (Medical \\ Research Council), London Hospital \\ (RECEIVED FOR PUBLICATION MAY 1, 1950)
}

Heinz (1890) gave the first detailed description of the changes which take place in the erythrocytes of rabbits during phenylhydrazine poisoning; 24 hours after the injection of $0 \cdot 1 \mathrm{~g}$. of phenylhydrazine into an animal a large number of the red cells of the blood showed rounded, highly refractile inclusions in their cytoplasm. The inclusions were generally situated eccentrically near the periphery of the cell, but some were found floating free in the plasma. Heinz called these structures Blaukörper, because when a vital staining technique was used they were shown as blue granules by methyl violet. Using a series of derivatives of phenylhydrazine and other related substances, he was able to produce similar changes in the blood of dogs and cats. Changes of the same nature had already been mentioned by Reis (1882) in connexion with sodium chlorate poisoning.

Roehl (1890), working independently, in the same year as Heinz observed a similar type of intracellular change in man during dinitrobenzene poisoning. Another early description of this phenomenon was given by Ehrlich (1892) who called the inclusions haemoglobinämiche Innenkörper, and noted that the appearance of the granulations was accompanied by a decrease in the hæmoglobin, although it is not clear whether this refers to the total hæmoglobin content of the blood or to the content of each cell. The intracellular inclusions produced by poisons such as phenylhydrazine have been variously referred to as Heinz bodies, Heinz-Ehrlich bodies, Innenkörper, inner bodies, Binnekorper, Innenkorpchen, and bodies of hæmoglobin degeneration. In the literature in English the term Heinz bodies is mainly used, but the subject as a whole seems to have attracted little attention in Britain.

The interest in the formation of Heinz bodies lies in the fact that, in general, they are produced by substances that also lead to the formation of methæmoglobin. The diagnostic significance of this was pointed out by Ehrlich (1892) and his views confirmed by Pappenheim and Suzuki (1912). More recently the suggestion has been made by Grosse, Bock, and Hellrung (1942) that the examination of a stained blood film is a very much simpler way of detecting the beginning of poisoning than is the more complicated estimation of methæmoglobin, and might be used during the routine clinical examination of workers handling organic nitro-compounds. There are, however, substances which, while they give rise to methæmoglobin formation, have not so far been shown to lead to the formation of Heinz bodies and vice versa. A stimulus to the study of this subject has been given by the demonstration by Moeschlin (1940) that sulphonamides may lead to the production of Heinz bodies, and that this change can be used as an indication of the possible production of clinical hamolytic anæmia by new compounds of the sulphonamide series. During the 1939-45 war the need for keeping a check on the health of munition workers, and the study of the toxicity of more nitrocompounds recently introduced into the explosives industry have also interested workers in the subject.

The Occurrence of Heinz Bodies in Clinical Practice

The cases in which Heinz bodies have been observed in the red cells of the blood of man fall into two groups, those due to exogenous and those to endogenous causes. In the first group some of the cases were due to accidental poisoning, mainly industrial, by substances such as dinitrobenzene, dinitrotoluene, and aniline, whilst others were due to the use of various drugs such as pyrodin and antifebrine. Ehlich and Lindenthal (1896) associated the appearance of Heinz bodies with nitrobenzene poisoning, and Zadek and Burg (1930) pointed out that the clinical significance of Heinz bodies is that the phenomenon is essentially connected with poisoning by compounds that also give rise to methæmoglobin. A possible exception to this may be found in the four cases of fulminating 
hæmolytic anæmia due to naphthalene poisoning described by Zuelzer and Apt (1949). Here no methæmoglobin could be detected and Heinz bodies were found in one case. These authors subsequently showed that naphthalene caused Heinz bodies in the dog, but made no mention of methæmoglobin in their animal experiments. Apart from this instance methæmoglobin has always been reported in association with Heinz bodies when it has been looked for, but this examination has not always been made, though many cases are reported where the formation of methæmoglobin and not of Heinz bodies was observed. This, of course, may be due to the fact that no attempt was made to look for them.

Schilling (1928) described the cases of two infants poisoned by aniline dye from cloth, and a case of antifebrine (acetanilide) poisoning. Ungricht (1938) described two cases of poisoning with Heinz body formation, one due to nitroglycerine and the other to acetylphenylhydrazine. Moeschlin $(1940,1941)$ reported the occurrence of Heinz bodies during sulphonamide therapy. Other cases are described by Roehl (1890), Heinz (1890), Freifeld, Schilowa, and Ludwinowsky (1937), Doering (1941), Wilhelmi (1942), and others. These cases, in all of which there was hæmolytic anæmia with more or less marked cyanosis, are summarized in the appendix.

Examples of the formation of Heinz bodies due to endogenous causes have been reported by Schilling (1928) in cases of malaria and blackwater fever, and following splenectomy by Ungricht (1938), and also by Zadek and Burg (1930). Another example of the formation of Heinz bodies due to endogenous causes is seen in the report of Schmauch (1899), who observed Heinz bodies in the blood of old cats.

\section{The Experimental Production of Heinz Bodies}

By far the greater part of the work to produce Heinz bodies experimentally has been carried out using phenylhydrazine, usually as the hydrochloride, or acetylphenyl hydrazine (pyrodin). All the earlier work was carried out in vivo and, indeed, Friedstein (1911) states that " the corpuscles are formed only in the body, not in vitro". Dogs, cats, rabbits, guinea-pigs, and mice have all been used as experimental animals for this purpose, and the toxic substances administered orally, by subcutaneous, intraperitoneal and intravenous injection in physiological fluid (Locke's fluid or isotonic saline), or in oil, by percutaneous absorption, and in one set of experiments by inhalation. Only comparatively recently has the problem been simplified by work in vitro.

Warburg, Kubowitz, and Christian (1931) used an in vitro technique for their work on the effect of phenylhydrazine and phenylhydroxylamine on the metabolism of red cells, but make no mention of the microscopic appearance of the cells. Bratley, Burroughs, Hamilton, and Kern (1931) first demonstrated the production of Heinz bodies by pyrodin in vitro by hanging drop preparations of erythrocytes suspended in isotonic saline. Using this method, without the aid of staining, they were able to follow the formation and growth of Heinz bodies in an erythrocyte. The in vitro method has since been used by Moeschlin (1941), by Dustin (1942), and by others, the blood, to which a known amount of the toxic substance in isotonic saline has been added, being maintained at $37^{\circ} \mathrm{C}$. using oxalate as the anticoagulant.

\section{Morphological Changes}

Heinz bodies can be seen in unstained preparations as refractile, rounded enclosures within the red cells of the blood. Bratley and others (1931) described and gave illustrations of their gradual formation and growth in the living cell ; using pyrodin as the toxic agent they saw single enclosures in some cells, whilst others contained up to four or five smaller bodies. Jung (1.942) investigated the formation of Heinz bodies using the electron microscope, and he was able to demonstrate that the early stages appear as submicroscopic inclusions which gradually grow and clump together. Under the electron microscope the Heinz bodies formed by different toxic agents do not present nearly so uniform an appearance as they do when stained and examined under the light objective, and it might be possible to distinguish which poison had been administered by the picture presented.

The number of bodies found in a cell varies and is a function of the concentration of poison to which the cell has been subjected; there is not yet sufficient data to show if it is also related to its chemical structure. Dustin (1943) studied the effect of concentrations of from 1 to $25 \mathrm{mg}$. \% of phenylhydrazine on the percentage of cells changed in vitro, and found that the number of cells containing a single Heinz body decreased when the concentration was raised or the time of action prolonged ; with higher concentrations of from 200 to $500 \mathrm{mg}$. \% there was a greatly increased number of fine punctations which were often of a smaller size than those of true basophilic punctation. He concludes that the two types of change are of the same kind, and the different appearance presented is merely a matter of the concentration of poison.

In in vivo experiments there is the possibility that species variations between different experimental animals may affect the number of inclusions found per cell, and Grosse and others (1942) noted that 
while nitroglycol in small quantities produced multiple cell inclusions in the dog and rabbit, similar doses produced only single inclusions in the cat. Wilhelmi (1942) using glycol dinitrate in doses of 22.5 to $50 \mathrm{mg}$. per $\mathrm{kg}$. body weight in cats found some cells with fine punctations which increased in number as time went on, and others with single, large, button-like bodies which increased in size until, six to eight hours after administration of the poison, they were from $1 / 6$ to $1 / 5$ of the size of the erythrocyte containing them. The cells containing these large, button-shaped inclusions were found to break down and disappear from the blood stream before the cells containing the smaller bodies. The length of time taken for the bodies to develop varies widely, and it is difficult to collect comparable data owing to the variety of toxic agents and methods of administration used. Bratley and others (1931) giving pyrodin in doses of $0.5 \mathrm{ml}$. of $1 \%$ solution to rabbits, probably equivalent to a dose of $2.5 \mathrm{mg}$. per $\mathrm{kg}$. body weight, and $2.0 \mathrm{ml}$. of $2 \%$ solution to dogs, a dose of 2 to $5 \mathrm{mg}$. per $\mathrm{kg}$. body weight, noted a " moth-eaten " appearance of the red blood cells on the third day after subcutaneous injection, and the first appearance of Heinz bodies on the fourth day. Lambrechts and Nizet (1943) using relatively much larger doses of 15 to $20 \mathrm{mg}$. per kg. body weight of phenylhydrazine intravenously in the dog found a rapid production of Heinz bodies, the number of cells involved reaching a total of $\mathbf{6 0}$ to $80 \%$ in the first two or three hours. A similar rapid rate of production was found by Dustin (1943) in his in vitro experiments with phenylhydrazine on human blood. Our own experiments in vitro confirm the results of Dustin, showing a production of Heinz bodies in 40 to $90 \%$ of the cells in the first four or five hours after the administration of a dose of phenylhydrazine equivalent to $10 \mathrm{mg}$. \%.

Moeschlin (1941) found spontaneous formation of Heinz bodies in control tubes of blood in his in vitro experiments, and Dustin (1943) noted the formation of very small inclusions in $19 \%$ of the cells in a control tube of oxalated blood kept at $37^{\circ} \mathrm{C}$. for 19 hours. We did not observe quite such high figures; the highest value obtained in our control tubes was $12 \%$ in 24 hours, with the more usual figures running around 5 to $6 \%$.

Kunkel (1912) saw the appearance of Heinz bodies 24 hours after injecting a mixture of toluene diamine and pyrodin, but two days after the injection he states that no inclusions could be seen. The formation of Heinz bodies is probably an irreversible reaction, and most authors, where follow-up examinations were made, report the persistence of the affected cells in the blood stream for some days after the administration of the poison. In the dog,
Lambrechts and Nizet (1943) found that it took up to 25 days before the blood was clear of Heinz bodies after phenylhydrazine poisoning. Grosse and others (1942) working on the effects of ethylene glycol dinitrate on cats noted that Heinz bodies persisted in the blood for some time after the methæmoglobinæmia had disappeared.

\section{Connexion with Methæmoglobin}

Other cell changes usually accompany the formation of Heinz bodies, namely a decrease in the functional hæmoglobin and in the fragility of the cells, and the appearance of methæmoglobin. The connexion between methæmoglobin and Heinz bodies has been much discussed and the matter has not yet been explained satisfactorily. Heinz body formation is always accompanied by a drop in the hæmoglobin level, and Lambrechts and Nizet (1943) found this drop to run parallel with the formation of Heinz bodies. Wilhelmi (1942) noted a fall in the hæmoglobin coincident with the destruction of the cells with the large, button-like inclusions. It was thought originally that there was a direct connexion between the formation of Heinz bodies and the formation of methæmoglobin, for it was noticed that Heinz bodies were formed under the influence of substances that also cause methæmoglobin. This is not the case, however, and all methæmoglobin-forming poisons have not been shown to produce Heinz bodies.

The relative speed of production of Heinz bodies and methæmoglobin by different poisons varies. According to von Bredow and Jung (1942) dinitrobenzene and trinitrobenzene, which both lead to Heinz body formation, show very similar timeaction curves for inclusion formation, though the curves representing methæmoglobin formation are very different, trinitrobenzene acting very rapidly, dinitrobenzene relatively slowly. Wilhelmi (1942) found that in cases of nitroglycerine poisoning there was a gradual increase in the number of Heinz bodies in the blood, whereas the methæmoglobin remained at a constant high level, and from this she concludes that Heinz body formation is independent of that of methæmoglobin, but there does appear to be a correlation between the degree of anæmia and the number of Heinz bodies formed.

Moeschlin (1941) claims a direct relation between the two changes, and states that Heinz bodies are always accompanied by methæmoglobin. He considers that this methæmoglobin catalyses the production of Heinz bodies from hæmoglobin. Heubner (1941) put forward a hypothesis connecting Heinz bodies and verdoglobins and thought that they were directly proportional, but in a later paper (1942) he considers the production of Heinz bodies, methæmo- 
globin, and verdoglobin by certain toxic substances to be a parallel process. Gajdos and Tiprez (1947) support the idea of a direct relationship with verdoglobin, and regard Heinz bodies as the morphological evidence of the degradation of hæmoglobin to bilirubinoids.

\section{Chemical Composition}

The protein nature of these structures is now established but the origin of the protein is still in doubt. Early workers thought that it originated in the protein fraction of hæmoglobin, and most of the subsequent work has been based on this assumption. Suzuki (1912) isolated Heinz bodies by hæmolysing the cells with distilled water and centrifuging out the residue, which he showed to be insoluble in a number of organic solvents. Hartwich (1912) showed that the residue obtained in this way contained a protein and a crystallizable substance which could be extracted with ether or chloroform ; this he thought to be a fatty acid. One objection to the validity of the results that Hartwick obtained is that Heinz bodies prepared in this way probably would have cell stroma adhering to them. Hartwick thought that Heinz bodies contained a hæmoglobin derivative which was neither pure hæmin nor hæmatoporphyrin, but contained iron in the ferrous state. Kunkel (1912) carried out a more extensive analysis on Heinz bodies prepared from the blood of rabbits poisoned with a mixture of toluene diamine and pyrodin. He found that the residue left after centrifuging hæmolysed, washed cells would dissolve in $10 \%$ acetic acid, and on spectrographic examination this solution gave a band in the blue-green; when the residue was dissolved in $\mathrm{N} / 10$ sodium hydroxide, however, there was a very weak band in the orange-yellow. He concluded that Heinz bodies contained "a histone denatured to a syntonin, a diamide-phosphatide linked to a protein, a small amount of cholesterol, and an iron-containing blood pigment derivative".

Chemical studies of phenylhydrazine poisoning by Warburg (1931) showed that there was the formation of a denatured globin with the liberation of hæmin. Heubner (1941) thought that Heinz bodies were formed from a modified globin, with the simultaneous formation of verdochromogen by the opening up of the hæm ring of four pyrole nuclei to form a straight chain. However, in 1942, work by Kriese and Seipelt, and Jung, Pulina, and Wilhelmi in that year led Heubner to change this view in favour of the theory that Heinz bodies arise from the denaturation of the cell membrane.

Dustin (1943) showed that Heinz bodies had the properties of an amphoteric protein with an isoelectric point of $5 \cdot 8$, as determined by Pishinger's method, which accounted for their staining reactions; also that Heinz bodies were not digested by ribonuclease at $p \mathrm{H} 6$ while the diffuse basophilism of young red cells, the substance of the reticular network and punctate basophilism, were digested under the same conditions. The isoelectric point of the cell stroma itself is $5 \cdot 2$, but Dustin does not think that Heinz bodies are formed only from the constituents of the cell stroma, because during the course of his experiments he noticed that a number of the cells completely lost their hæmoglobin whilst the stroma retained its form and carried clusters of Heinz bodies.

Schilling (1921), considering whether the origin of Heinz bodies was nuclear or cytoplasmic, thought that they were of cytoplasmic origin, and were preformed in normal erythrocytes as the "capsular body", and he thus fitted them into his scheme of the anatomy of the erythrocyte. Deutche's work (1928) also led him to conclude that Heinz bodies were not a nuclear product. Even so, despite a!l the evidence to the contrary, Heinz bodies have been identified with Schmauchers bodies, Jolly bodies, Howell bodies, and nuclear remains.

\section{Other Cell Changes}

Suzuki (1912) reported an increased resistance to hæmolysis of cells which contained Heinz bodies produced in vivo; he states that " the resistance was due not so much to a diffuse pachydermy as to the presence of the insoluble, resistant Heinz bodies". This decreased fragility is noted by several other authors, particularly by Cruz (1941).

Bratley and others (1931) studied the effect of poisoning dogs and rabbits with phenylhydrazine and pyrodin, and noted that these poisons produced changes in the cell size and shape, both anisocytosis and poikilocytosis being observed. Against these observations must be set the work of Lambrechts and Nizet (1943) who, in a paper devoted to this subject, reported no anisocytosis in the dog after the intravenous injection of phenylhydrazine.

The effect on the cell membrane differs with the poison used; Jung (1942) found no change in the membrane during dinitrobenzene poisoning, whereas with phenylenediamine all stages of a gradual destruction of the membrane could be seen under the electron microscope.

\section{Response of Cells of Different Ages}

The consensus of opinion is that Heinz bodies are only to be found in the mature erythrocytes, but using the light ground technique it is often almost impossible to distinguish between a late-stage reticulocyte and a mature cell containing small Heinz bodies. Cruz (1941), 24 hours after the 
injection of pyrodin into dogs and rabbits, in doses of $19 \mathrm{mg}$. and $14 \mathrm{mg}$. per $\mathrm{kg}$. body weight respectively, found inclusions in all the adult red cells but never in the reticulocytes. Grosse and others (1942) reported the formation of Heinz bodies in all the erythrocytes of the circulating blood, but made no special mention as to whether they include reticulocytes or not, and Wilhelmi (1942) said that small bodies were formed in the young cells under the influence of glycoldinitrate. Ungricht (1938) describes two cases of methæmoglobinæmia, one due to nitroglycerine poisoning, the other to acetylphenylhydrazine ; in the first case Heinz bodies in the cells of the peripheral blood reached a maximum of $23.5 \%$ and were also found in the bone marrow but "very seldom in reticulated erythrocytes". In a case of splenectomized familial hæmolytic jaundice $3.2 \%$ of cells containing Heinz bodies were seen in the peripheral blood, and $8.3 \%$ in the bone marrow.

Moeschlin (1941) believed the absence of Heinz bodies in reticulocytes to be due to the fact that they take two or three days to develop in vivo, and this time is similar to that required for the maturation of a reticulocyte. This view conflicts with Lambrechts and Nizet's (1943) experiment in which Heinz bodies were formed in 60 to $80 \%$ of cells two to three hours after the injection of phenylhydrazine. Lambrechts and Nizet, however, were using more massive doses than Moeschlin.

\section{Staining Characteristics of Heinz Bodies and their Distinction from Reticulocytes}

The appearance and staining characteristics of Heinz bodies are somewhat similar to those of reticulocytes, and it is more than probable that in the past these two structures have been confused. Various methods of distinguishing between them have been suggested: the size of the cell, the appearance of the network or punctations, the degree of staining, the more basophilic cytoplasm of the reticulocyte, and even digestion with ribonuclease, but the best method so far suggested is undoubtedly that of Lambrechts and Nizet (1943). This method consists of dark ground examination of a dried blood film stained with brilliant cresyl blue. Under these conditions the reticular substance shows up a clear yellow, the Heinz bodies brick-red, and the cell outline a dull wine-red. The staining is carried out and the film prepared in the same way as for routine reticulocyte counts. In our work the wet method of staining was used rather than that in which a film of blood is made on a dry film of stain on the slide, because we found that with this method a wet-mount preparation can also be examined, a small drop of stained blood being placed under a coverslip and sealed round with vaseline to prevent evaporation. Although this wet mount has not the advantage of giving a permanent record that a dry film has, it does allow the examination of cells of an undistorted shape, so long, of course, as the stain used is isotonic ; also counting is less interfered with by the presence of dust particles or precipitated stain than is the case in the dry preparation. The dry, unmounted films keep quite well, or they may be mounted in cedarwood oil.

If the illumination is good Heinz bodies can be seen in an unstained, fresh, wet preparation. Heinz himself demonstrated them by vital staining using methyl violet, and Ehrlich used a similar method. If a supravital staining technique using neutral red and Janus green is adopted the Heinz bodies take up the neutral red. They may be stained post-vitally by any of the usual basophilic stains : Nile blue, brilliant cresyl blue, Bismarck brown, azur 11 or neutral-red ; of these, brilliant cresyl blue and Nile blue seem to be the best. Dustin (1943) reports that Heinz bodies are also stained by acid dyes buffered to a low $p \mathrm{H}$, and staining with these dyes may be carried out before or after fixation. Using panoptic methods of staining Heinz bodies do not show any basophilic properties, and, unlike the substance of the reticular network, they lose their basophilism on fixation. We have found it inadvisable to counterstain, as is usually done in the routine reticulocyte method for staining for light ground examination, because the basic dye is often washed out of the Heinz bodies.

The compounds which are known to produce Heinz bodies may be classed into the following broad groups : hydroxylamine ; aromatic nitrogen compounds of the nitro-benzene series; aromatic nitrogen compounds related to aniline; aliphatic nitro-compounds ; sodium nitrite; sodium nitrate ; sodium chlorate; naphthalene.

It is not possible at present to make any comparison of the activity of different substances which cause Heinz bodies owing to the varying technique and different compounds used by workers on the subject. Moeschlin (1941) tries to correlate the chemical structure of the various sulphonamides with their production of Heinz bodies and bacterial action. The work which has been done on the different groups is summarized in the appendix.

\section{Summary}

That Heinz bodies are a definite structure formed in the erythrocyte and not an artefact arising from the method of examination as has sometimes been suggested, would seem to be established by the mass of evidence now published. But this is about as far as that knowledge really goes. The biochemical 
nature of Heinz bodies is still not fully understood, and with a more complete knowledge, insight into the chemical changes causing their production should be gained.

\section{REFERENCES*}

Alcobe, S. (1929-30). Beitr. path. Anat., 83, 313.

Bratley, F. G., Burroughs, H. H., Hamilton, D. M., and Kern, C. (1931). Amer. J. med. Sci., 182, 597.

Bredow, yon M., and Jung, F. (1942). Arch. exp. Path. Pharmak. 200,335 .

Cruz, W. O.(1941). Amer. J. med. Sci., 202, 781.

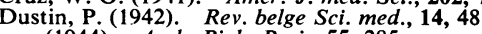

(1944). Arch. Biol., Paris, 55, 285.

Fertman, M. H., and Doan, C. A. (1948). Blood, 3, 349.

Figge, F. H. J. (1946). Anat. Rec., 94, 461.

Gajdos, A. (1947). Sang, 18, 30

, and Tiprez, G. (1947). Ibid., 18, 35.

Grosse, E., Bock, M., and Hellrung, F. (1942). Arch. exp. Path. Pharmak. 200, 271 .

Hartwich, W. (1912). Folia haemat., Lpz., 13, 257.

Heubner, W. (1941).

Jung, F. (1942). Whid.,21, 517 .

Kunkel, H. (1912). Folia haemat., Lpz., 14, 430

Lambrechts, A., Nizet, A., and Lacasse, P. (1943). Acta biol. belg., 3,202 .

(1943). Ibid., 3, 203.

- - , (1943). Ibid., 3, 199.

Moeschlin, S. (1940). Schweiz. med. Wschr, 70, 786

(1941). Ibid., 71, 789.

(1941). Folia haemat., Lpz., 65, 345.

_ and Hurschler, H. (1940). Schweiz. med. Wschr., 70, 972

Nizet, A. (1947). Quart. J. exp. Physiol., 34, 43.

Pappenheim, A., and Suzuki, T. (1912). Folia haemat. $L_{1} z ., 13,205$

Ponder, E., and Velick, S. (1939-40). J. Physiol., 97, 5p.

Pulina, B. (1942). Archiv. exp. Path. Pharmak.. 200, 324

Richardson, A. P. (1940). J. Pharmacol., 70, 370.

Strampelli, B. (1930). Haematologica, 11, 397

Suzuki, T. (1912). Folia haemat., Lpz., 13, 225.

Ungricht, M. (1938). Ibid., 50, 145.

Warburg, O., Kubowitz, F., and Christian, W. (1931). Biochem. Z., 242,170 .
Wilhelmi, H. (1942). Arch. f. exp. Path. Pharmak., 200, 305.

Zadek, I and Burg, K. (1930) Folia haemat, LpZ, 41, 333

Zuelzer, W. D., and Apt, L. (1949). J. Amer. med. Ass., 141, 185.

The following papers were seen in abstract only.

Deutche, I. (1928) $Z$ Z klin. Med., 108, 747.

Doering, L. (1941). . Med. Klinik, 37, 354.

Donner, (1945). Cas. Lék. čes., p. 536.

Ehrlich, P. (1892). Verh. Kongr. inn. Med., 11, 33

Ehlich, K., and Lindenthal, O. (1896). Z. klin. Med., 30, 427.

Freifeld, H., Schilowa, A., and Ludwinowsky, R. (1937). Folia haemat., Lpz., 56, 333.

Friedstein, D. (1911). Ibid., 12, 239.

Gutstein, M., and Wallbach, G. (1928). Virchows Arch., 267, 144.

Heinz, R. (1890). Ibid., 122, 100

-1890). Berl. klin. Wschr., 27, 47.

-(1899). Virchows Arch., 156, 201.

(18901). Virchows Arch., 156, 201.

(1901). Beitr. path. Anat., 29, 299.

Heubner, W. (1941). Klin. Wschr., 20, 137.

Houštěk, J. (1947). Cias. Lék. ïes., 86, 289.

Huber, A. (1891). Virchows Arch., 126, 240.

Jung, F. (1942). Naturwissen schafter, 30, 473.

Kiese, M., and Seipelt, L. (1942). Arch. exp. Path. Pharmak., 200, 648 .

Markoff, N. G. (1943). Schweiz. med. Wschr., 73, 636.

Pimenta de Mello, R. (1945). Rev. brasil. Biol., 5, 387. (BA 1946

A III 886).
Reis. (1882). Berl. , klin. Wschr., p. 572.

Rejsek, K. (1944). Cas. Lék. Wes., p. 1442.

Rejsek, K. (1944). Cas. Lék.

Roehl. (1890). Diss., Rostock.

Schilling, V. (1933). Verh. dtsch. Ges. inn. Med. 45, 104.

-(1921). Dtsch. med. Wschr., 47, 825.

- (1921). Virchows Arch., 234, 548

(1928). Z. klin. Med, 108, 709

Schmauch, G. (1899). Virchows Arch., 156, 201

Schwalbe, E., and Solley, J. (1902). Ibid., 168, 392.

Sokolovskaya, Y. Y. (1948). Arkh. Patol., 10;4), 9. (Abstract in British Abstracts A III, June 1949)

* Since the completion of this review the following references have come to hand :

Jung, F. (1949). Arch. exp. Path. Pharmak., 208, 21

Reimer, E. E. (1950). Wein. klin. Wschr., 62, 26. 
A P P E N D I X

Substances Producing Heinz Bodies

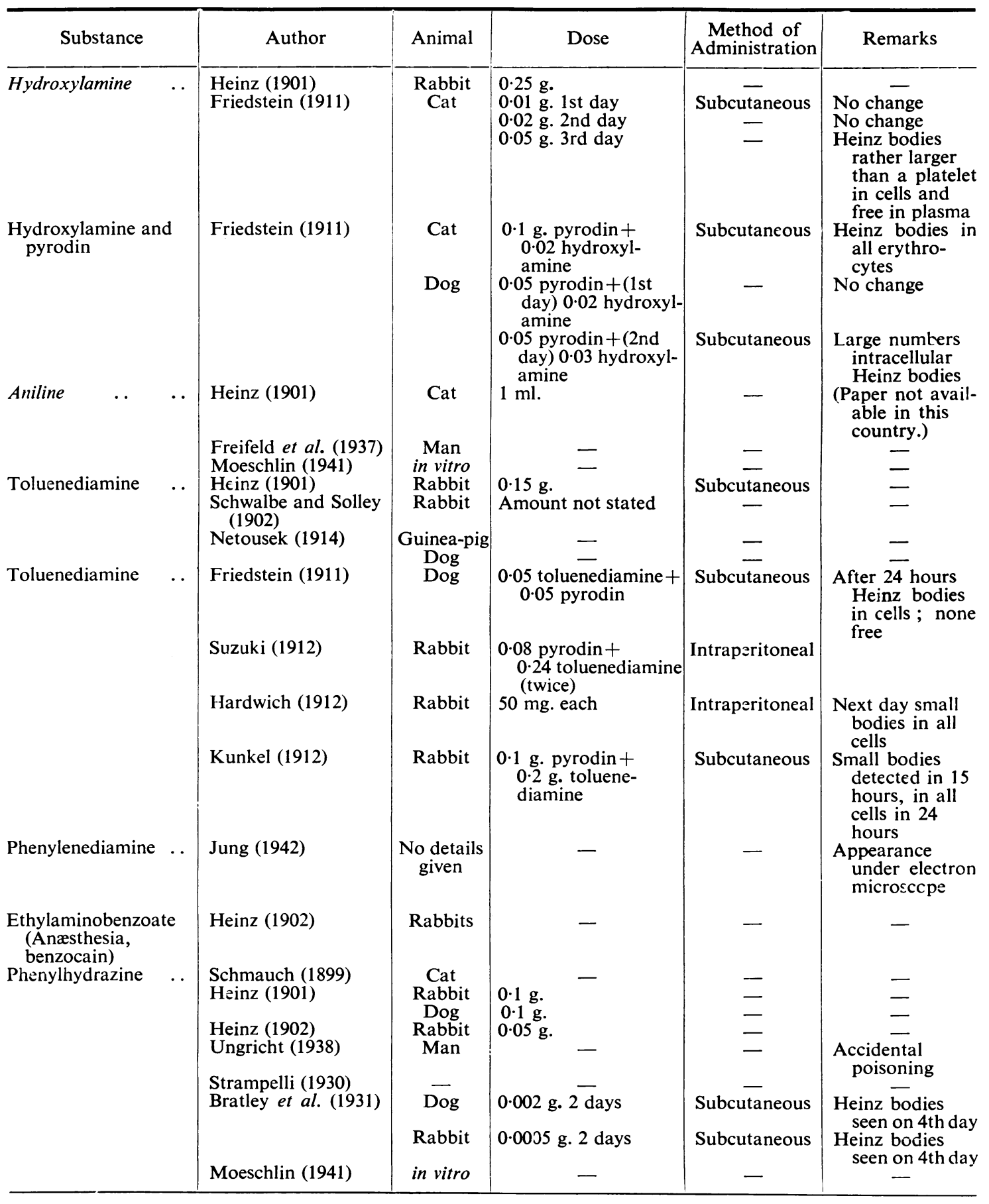


APPENDIX-Continued

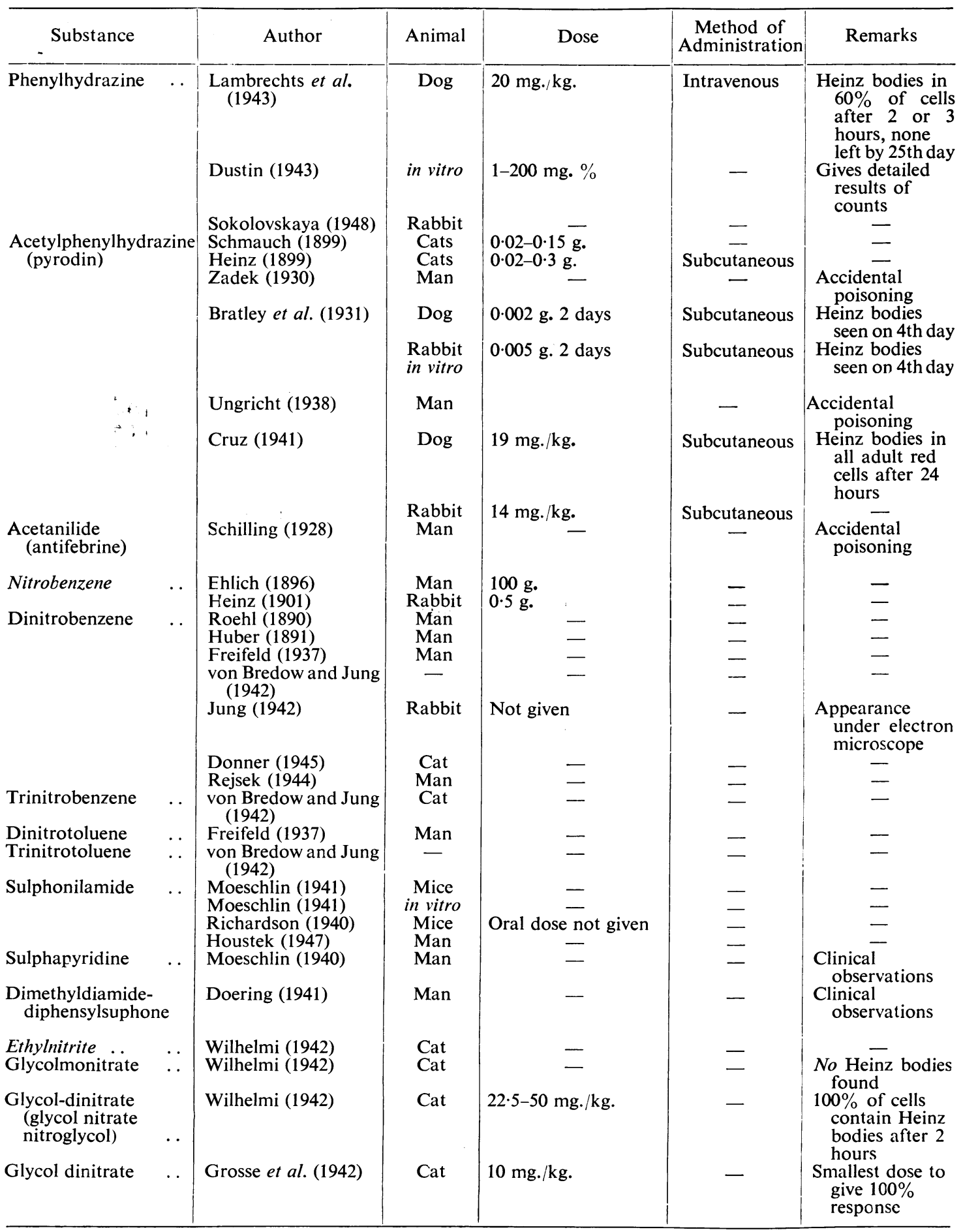

[Continued on next page 
APPENDIX-Continued

\begin{tabular}{|c|c|c|c|c|c|c|}
\hline Substance & & Author & Animal & Dose & $\begin{array}{l}\text { Method of } \\
\text { Administration }\end{array}$ & Remarks \\
\hline Glycol dinitrate & .. & Jung (1942) & Cat & $\begin{array}{l}4 \times 6 \mathrm{~cm} \text {. gauze soaked } \\
\text { in substance } \\
0.13 \mathrm{mg} . / 1 \text { ( } 20 \text { p.p.m.) } \\
0.134 \mathrm{mg} . / \mathrm{l}(21 \text { p.p.m.) } \\
-\end{array}$ & $\begin{array}{l}\text { Inhalation } \\
\text { Inhalation } \\
\text { - }\end{array}$ & $\begin{array}{l}\text { Heinz bodies in } \\
\text { circulating } \\
\text { blood after } 70 \\
\text { hours } \\
\text { Moderate tem- } \\
\text { porary blood } \\
\text { changes } \\
\text { Marked blood } \\
\text { change } \\
\text { Appearance } \\
\text { under electron } \\
\text { microscope }\end{array}$ \\
\hline $\begin{array}{l}\text { Nitroglycerine } \\
\text { Sodium nitrite }\end{array}$ & .. & $\begin{array}{l}\text { Ungricht (1938) } \\
\text { Grosse et al. (1942) } \\
\text { Wilhelmi (1942) } \\
\text { Moeschlin (1940) }\end{array}$ & $\begin{array}{l}\text { Man } \\
\text { Cat } \\
\text { Man } \\
\text { Mice }\end{array}$ & $\begin{array}{r}\overline{-} \\
\overline{\overline{\mathrm{g}}}\end{array}$ & $\bar{z}$ & $\begin{array}{c}\text { - } \\
\text { Factory workers } \\
-\end{array}$ \\
\hline $\begin{array}{l}\text { Sodium nitrate } \\
\text { Sodium chlorate }\end{array}$ & .. & $\begin{array}{l}\text { Pulina (1942) } \\
\text { Heubner (1942) } \\
\text { Reis (1882) }\end{array}$ & E & $=$ & $\begin{array}{c}\text { - } \\
\text { - }\end{array}$ & = \\
\hline Naphthalene & .. & $\begin{array}{l}\text { Zuelzer and Apt } \\
\text { (1949) }\end{array}$ & $\begin{array}{l}\text { Dog } \\
\text { Man }\end{array}$ & $\begin{array}{l}3,9,12 \mathrm{~g} \cdot \text { per animal } \\
3 \mathrm{~g} .\end{array}$ & $\begin{array}{l}\text { Orally } \\
\text { Orally }\end{array}$ & $\begin{array}{l}\text { Heinz bodies in } \\
\text { blood on } 2 \text { nd } \\
\text { day } \\
\text { Children sucking } \\
\text { moth-balls. } \\
\text { Clinical } \\
\text { history }\end{array}$ \\
\hline
\end{tabular}

